\title{
Investigations of a Gas Turbine Low-Emission Combustor Operating on the Synthesis Gas
}

\author{
Serhiy Serbin and Nataliia Goncharova \\ Admiral Makarov National University of Shipbuilding, Mykolaiv, Ukraine \\ Correspondence should be addressed to Serhiy Serbin; siserbin@yandex.ru
}

Received 3 November 2016; Revised 24 February 2017; Accepted 12 March 2017; Published 5 April 2017

Academic Editor: Nandkishor Nere

Copyright @ 2017 Serhiy Serbin and Nataliia Goncharova. This is an open access article distributed under the Creative Commons Attribution License, which permits unrestricted use, distribution, and reproduction in any medium, provided the original work is properly cited.

\begin{abstract}
Investigations of the working processes in a gas turbine low-emission combustor operating on the synthesis gas, in which the principle of RQL (Rich-Burn, Quick-Mix, and Lean-Burn) combustion technology is realized, have been performed. Selected concept of a gas turbine combustor can provide higher performance and lower emission of nitrogen oxides and demonstrates satisfactory major key parameters. Obtained results and recommendations can be used for the gas turbine combustor operation modes modeling, geometry optimization, and prospective power generation units design and engineering.
\end{abstract}

\section{Introduction}

Gas turbine engines (GTE) are designed primarily to be fueled with natural gas, which mainly consists of methane. Recent increases in natural gas prices and concerns about its availability, as well as significant advances in synthesis gas producing and cleanup, have made opportunities for the synthesis gas as a primary GTE fuel [1].

Plasma-assisted gasification can be efficiently used to convert carbon-containing materials to synthesis gas that can be used to generate power [2-10].

Rather serious increase of toxic substances emission is possible when using synthetic fuels in GTE combustors in comparison to engines which operate on traditional fuel. Thus, there is necessity to provide design solutions for hazardous elements emission mitigation.

Almost all the known methods of $\mathrm{NO}_{x}$ emission suppression (during synthetic fuel combustion) are connected with decreasing of temperature in the reacting zone or the volume of the high-temperature zones. These methods are the following: combustion of lean preliminary mixed air-fuel mixtures; combustion according to the "Rich-Burn, QuickMix, and Lean-Burn" scheme (RQL scheme); water or water steam injection to the combustor; catalytic burning $[7,11]$.
RQL combustion scheme includes initial combustion of rich air-fuel mixture and quick mixing and burning of lean air-fuel mixture [12]. Combustor is divided into two zones. The first zone shall provide stable combustion of fuel-rich mixture with a relatively low temperature and a low amount of an oxidant (under these conditions nitrogen oxide formation is low). The second zone (after quick and uniform mixing with an oxidant) provides combustion of fuel-lean mixture at which nitrogen oxide formation is low as well. It should be mentioned that the main problem of this combustion technology is providing quick and qualitative mixing of the flows of an oxidant and the products of hydrocarbons partial oxidation at the intermediate stage (Quick-Mix) [13] in order to avoid forming mixture with stoichiometric content in some local zones of the combustor. If there is stoichiometric content, there will be high temperatures and a high level of nitrogen oxide emission.

Selection of rational correlations of geometry parameters of this two-zone combustor which operates on synthesis gas and defining the most effective ways of oxidant (air) supply to the zone of quick mixing is a rather important practical issue. Its solution through experimental means requires high expenses of material and human resources. So using the computational models will provide sharp reduction of time 
TABLE 1: Reactions of reduced mechanism.

\begin{tabular}{|c|c|c|}
\hline $\mathrm{H}+\mathrm{O}_{2} \longrightarrow \mathrm{OH}+\mathrm{O}$ & $\mathrm{OH}+\mathrm{O} \longrightarrow \mathrm{H}+\mathrm{O}_{2}$ & $\mathrm{O}+\mathrm{H}_{2} \longrightarrow \mathrm{OH}+\mathrm{H}$ \\
\hline $\mathrm{OH}+\mathrm{H} \longrightarrow \mathrm{O}+\mathrm{H}_{2}$ & $\mathrm{OH}+\mathrm{H}_{2} \longrightarrow \mathrm{H}_{2} \mathrm{O}+\mathrm{H}$ & $\mathrm{H}_{2} \mathrm{O}+\mathrm{H} \longrightarrow \mathrm{OH}+\mathrm{H}_{2}$ \\
\hline $\mathrm{OH}+\mathrm{OH} \longrightarrow \mathrm{H}_{2} \mathrm{O}+\mathrm{O}$ & $\mathrm{H}_{2} \mathrm{O}+\mathrm{O} \longrightarrow \mathrm{OH}+\mathrm{OH}$ & $\mathrm{H}+\mathrm{O}_{2}+\mathrm{M} \longrightarrow \mathrm{HO}_{2}+\mathrm{M}$ \\
\hline $\mathrm{HO}_{2}+\mathrm{H} \longrightarrow \mathrm{OH}+\mathrm{OH}$ & $\mathrm{HO}_{2}+\mathrm{H} \longrightarrow \mathrm{H}_{2}+\mathrm{O}_{2}$ & $\mathrm{HO}_{2}+\mathrm{OH} \longrightarrow \mathrm{H}_{2} \mathrm{O}+\mathrm{O}_{2}$ \\
\hline $\mathrm{CO}+\mathrm{OH} \longrightarrow \mathrm{CO}_{2}+\mathrm{H}$ & $\mathrm{CO}_{2}+\mathrm{H} \longrightarrow \mathrm{CO}+\mathrm{OH}$ & $\mathrm{CH}_{4}(+\mathrm{M}) \longrightarrow \mathrm{CH}_{3}+\mathrm{H}(+\mathrm{M})$ \\
\hline $\mathrm{CH}_{3}+\mathrm{H}(+\mathrm{M}) \longrightarrow \mathrm{CH}_{4}(+\mathrm{M})$ & $\mathrm{CH}_{4}+\mathrm{H} \longrightarrow \mathrm{CH}_{3}+\mathrm{H}_{2}$ & $\mathrm{CH}_{3}+\mathrm{H}_{2} \longrightarrow \mathrm{CH}_{4}+\mathrm{H}$ \\
\hline $\mathrm{CH}_{4}+\mathrm{OH} \longrightarrow \mathrm{CH}_{3}+\mathrm{H}_{2} \mathrm{O}$ & $\mathrm{CH}_{3}+\mathrm{H}_{2} \mathrm{O} \longrightarrow \mathrm{CH}_{4}+\mathrm{OH}$ & $\mathrm{CH}_{3}+\mathrm{O} \longrightarrow \mathrm{CH}_{2} \mathrm{O}+\mathrm{H}$ \\
\hline $\mathrm{CH}_{2} \mathrm{O}+\mathrm{H} \longrightarrow \mathrm{HCO}+\mathrm{H}_{2}$ & $\mathrm{CH}_{2} \mathrm{O}+\mathrm{OH} \longrightarrow \mathrm{HCO}+\mathrm{H}_{2} \mathrm{O}$ & $\mathrm{HCO}+\mathrm{H} \longrightarrow \mathrm{CO}+\mathrm{H}_{2}$ \\
\hline $\mathrm{HCO}+\mathrm{M} \longrightarrow \mathrm{CO}+\mathrm{H}+\mathrm{M}$ & $\mathrm{CH}_{3}+\mathrm{O}_{2} \longrightarrow \mathrm{CH}_{3} \mathrm{O}+\mathrm{O}$ & $\mathrm{CH}_{3} \mathrm{O}+\mathrm{H} \longrightarrow \mathrm{CH}_{2} \mathrm{O}+\mathrm{H}_{2}$ \\
\hline $\mathrm{CH}_{3} \mathrm{O}+\mathrm{M} \longrightarrow \mathrm{CH}_{2} \mathrm{O}+\mathrm{H}+\mathrm{M}$ & $\mathrm{HO}_{2}+\mathrm{HO}_{2} \longrightarrow \mathrm{H}_{2} \mathrm{O}_{2}+\mathrm{O}_{2}$ & $\mathrm{H}_{2} \mathrm{O}_{2}+\mathrm{M} \longrightarrow \mathrm{OH}+\mathrm{OH}+\mathrm{M}$ \\
\hline $\mathrm{OH}+\mathrm{OH}+\mathrm{M} \longrightarrow \mathrm{H}_{2} \mathrm{O}_{2}+\mathrm{M}$ & $\mathrm{H}_{2} \mathrm{O}_{2}+\mathrm{OH} \longrightarrow \mathrm{H}_{2} \mathrm{O}+\mathrm{HO}_{2}$ & $\mathrm{H}_{2} \mathrm{O}+\mathrm{HO}_{2} \longrightarrow \mathrm{H}_{2} \mathrm{O}_{2}+\mathrm{OH}$ \\
\hline \multicolumn{2}{|c|}{$\mathrm{H}+\mathrm{OH}+\mathrm{M} \longrightarrow \mathrm{H}_{2} \mathrm{O}+\mathrm{M}$} & $\mathrm{M}$ \\
\hline
\end{tabular}

and resources for designing a RQL-combustor working on the synthesis gas.

\section{Approaches and Methods}

An offered CFD mathematical model of a combustor working on the synthesis gas is based on the following equations [1416]: continuity equation, momentum conservation equation, energy conservation equation, and mass conservation equation for main chemical components of the mixture. These equations are closed by adding proper differential equations of the turbulence model.

For the modeling of synthesis gas combustion processes the Eddy Dissipation Concept (EDC) model is used. It is an expanded model of turbulent eddy dissipation which includes low-level modeling of chemical processes of fuel oxidation under the conditions of flame with turbulent flow excitations [17].

The selection of a hydrodynamic turbulence model significantly influences the estimated properties of a mathematical model of a low-emission gas turbine combustor. The RNG modification of the $k-\varepsilon$ turbulence model has been used for the calculations. The advantages of this model are stable convergence and minimal resource expenses.

Combustion of synthesis gas requires attention to key operation processes factors, including emission formation. The range of compositions found in synthesis gas varies more substantially than similar properties of natural gas. Synthesis gas behaves differently in many ways including specific heat, diffusivity, flammability limits, and flame speed [18]. It restricts possibilities of using preliminary fuel-air mixing principle concerning synthesis gases with low calorific values and compositions which have changed in a wide range.

The study of modern gas turbine burning system operation shows that the diffusion-type burners show more stable results and have a more flexibility options in comparison with combustors even with partial preliminary mixing of different fuels with an oxidant [12].

If fuel has such components as $\mathrm{CO}, \mathrm{H}_{2}$, and $\mathrm{CH}_{4}$, then in terms of numerical modeling of combustion processes there should be grounded selection of the most proper kinetic schemes for defining the main flame parameters at reasonable computational efforts.
The detailed expanded chemical mechanisms which describe combustion of hydrocarbon fuel are developed properly for combustion of $\mathrm{CO} / \mathrm{H}_{2}$ mixtures. There are also additional simplified or so-called global mechanisms for CFD modeling which are mainly used for calculations of oxidation of hydrocarbon fuels and synthesis gases. For example, Bohni and others developed a six-stage kinetic mechanism by means of systematic decrease of the detailed kinetic mechanism and Andrea de Pascale and others offered a two-stage global mechanism for $\mathrm{CO} / \mathrm{H}_{2}$ mixtures [19].

Two mechanisms of chemical kinetics were used in this investigation to provide the detailed analysis of operating processes: (1) a simplified 35-reaction reduced mechanism [20] (Table 1) obtained by changing of multireaction kinetic scheme GRI-Mech [21] and (2) kinetic Yetter mechanism, offered by Yetter (Pennsylvania State University), Dryer, and Rabitz (Princeton University) [22] (Table 2).

The main chemical components of reduced mechanism are $\mathrm{CH}_{4} ; \mathrm{O}_{2} ; \mathrm{CO}_{2} ; \mathrm{CO} ; \mathrm{H}_{2} \mathrm{O} ; \mathrm{H} ; \mathrm{OH} ; \mathrm{O} ; \mathrm{H}_{2} ; \mathrm{HO}_{2} ; \mathrm{CH}_{3} ; \mathrm{HCO}$; $\mathrm{CH}_{3} \mathrm{O} ; \mathrm{CH}_{2} \mathrm{O} ; \mathrm{H}_{2} \mathrm{O}_{2} ; \mathrm{N}_{2}$.

The main chemical components of Yetter mechanism are $\mathrm{H}_{2} ; \mathrm{H} ; \mathrm{O}_{2} ; \mathrm{O} ; \mathrm{OH} ; \mathrm{H}_{2} \mathrm{O} ; \mathrm{HO}_{2} ; \mathrm{H}_{2} \mathrm{O}_{2} ; \mathrm{CO} ; \mathrm{CO}_{2} ; \mathrm{HCO} ; \mathrm{N}_{2}$; AR.

To verify a mathematical model of a combustor, which operates on synthesis gas, an ejection type afterburner of synthesis gas [6] was chosen as a research object.

For designing an afterburner the following initial data were accepted: synthesis gas consumption $25 \mathrm{~g} / \mathrm{s}$; temperature $\leq 700 \mathrm{~K}$; air flow via an afterburner $400 \mathrm{~g} / \mathrm{s}$; air temperature $350 \mathrm{~K}$. As the pressure of the obtained synthesis gas is close to the atmospheric one, an original ejection system is developed for providing synthesis gas supply to the afterburner.

The data acquisition scheme is shown in Figure 1 [6].

Air from the compressor 3 is fed into the afterburner fullsize model 1 through the Coriolis flowmeter 2 with capacity of 0 to $0.5 \mathrm{~kg} / \mathrm{s}$. Air from a compressor is introduced through the inlet duct and enters the receiver where it divides into five streams. The first stream enters an injector through three channels. Fuel gas enters through a pipe, injects through the injector, partially mixes with air in a mixer, and enters a flame tube. The second air flow enters a swirler, as a swirling flow enters the flame tube, forming a vortex type 
TABLE 2: Reactions of Yetter mechanism.

\begin{tabular}{|c|c|c|}
\hline $\mathrm{H}+\mathrm{O}_{2}=\mathrm{O}+\mathrm{OH}$ & $\mathrm{H}+\mathrm{O}_{2}+\mathrm{N}_{2}=\mathrm{HO}_{2}+\mathrm{N}_{2}$ & $\mathrm{H}_{2} \mathrm{O}_{2}+\mathrm{O}=\mathrm{OH}+\mathrm{HO}_{2}$ \\
\hline $\mathrm{O}+\mathrm{H}_{2}=\mathrm{H}+\mathrm{OH}$ & $\mathrm{H}+\mathrm{O}_{2}+\mathrm{AR}=\mathrm{HO}_{2}+\mathrm{AR}$ & $\mathrm{H}_{2} \mathrm{O}_{2}+\mathrm{OH}=\mathrm{H}_{2} \mathrm{O}+\mathrm{HO}_{2}$ \\
\hline $\mathrm{OH}+\mathrm{H}_{2}=\mathrm{H}+\mathrm{H}_{2} \mathrm{O}$ & $\mathrm{HO}_{2}+\mathrm{H}=\mathrm{H}_{2}+\mathrm{O}_{2}$ & $\mathrm{CO}+\mathrm{O}+\mathrm{N}_{2}=\mathrm{CO}_{2}+\mathrm{N}_{2}$ \\
\hline $\mathrm{OH}+\mathrm{OH}=\mathrm{O}+\mathrm{H}_{2} \mathrm{O}$ & $\mathrm{HO}_{2}+\mathrm{H}=\mathrm{OH}+\mathrm{OH}$ & $\mathrm{CO}+\mathrm{O}+\mathrm{AR}=\mathrm{CO}_{2}+\mathrm{AR}$ \\
\hline $\mathrm{H}_{2}+\mathrm{N}_{2}=\mathrm{H}+\mathrm{H}+\mathrm{N}_{2}$ & $\mathrm{HO}_{2}+\mathrm{O}=\mathrm{OH}+\mathrm{O}_{2}$ & $\mathrm{CO}+\mathrm{O}_{2}=\mathrm{CO}_{2}+\mathrm{O}$ \\
\hline $\mathrm{H}_{2}+\mathrm{AR}=\mathrm{H}+\mathrm{H}+\mathrm{AR}$ & $\mathrm{HO}_{2}+\mathrm{OH}=\mathrm{H}_{2} \mathrm{O}+\mathrm{O}_{2}$ & $\mathrm{CO}+\mathrm{OH}=\mathrm{CO}_{2}+\mathrm{H}$ \\
\hline $\mathrm{O}+\mathrm{O}+\mathrm{N}_{2}=\mathrm{O}_{2}+\mathrm{N}_{2}$ & $\mathrm{HO}_{2}+\mathrm{HO}_{2}=\mathrm{H}_{2} \mathrm{O}_{2}+\mathrm{O}_{2}$ & $\mathrm{CO}+\mathrm{HO}_{2}=\mathrm{CO}_{2}+\mathrm{OH}$ \\
\hline $\mathrm{O}+\mathrm{O}+\mathrm{AR}=\mathrm{O}_{2}+\mathrm{AR}$ & $\mathrm{H}_{2} \mathrm{O}_{2}+\mathrm{N}_{2}=\mathrm{OH}+\mathrm{OH}+\mathrm{N}_{2}$ & $\mathrm{HCO}+\mathrm{N}_{2}=\mathrm{H}+\mathrm{CO}+\mathrm{N}_{2}$ \\
\hline $\mathrm{O}+\mathrm{H}+\mathrm{M}=\mathrm{OH}+\mathrm{M}$ & $\mathrm{H}_{2} \mathrm{O}_{2}+\mathrm{AR}=2 \mathrm{OH}+\mathrm{AR}$ & $\mathrm{HCO}+\mathrm{H}=\mathrm{CO}+\mathrm{H}_{2}$ \\
\hline $\mathrm{H}+\mathrm{OH}+\mathrm{N}_{2}=\mathrm{H}_{2} \mathrm{O}+\mathrm{N}_{2}$ & $\mathrm{H}_{2} \mathrm{O}_{2}+\mathrm{H}=\mathrm{H}_{2} \mathrm{O}+\mathrm{OH}$ & $\mathrm{HCO}+\mathrm{O}_{2}=\mathrm{CO}+\mathrm{HO}_{2}$ \\
\hline $\mathrm{HCO}+\mathrm{O}=\mathrm{CO}+\mathrm{OH}$ & $\mathrm{H}_{2} \mathrm{O}_{2}+\mathrm{H}=\mathrm{H}_{2}+\mathrm{HO}_{2}$ & $\mathrm{HCO}+\mathrm{OH}=\mathrm{CO}+\mathrm{H}_{2} \mathrm{O}$ \\
\hline $\mathrm{H}-$ & & $+\mathrm{AR}$ \\
\hline
\end{tabular}

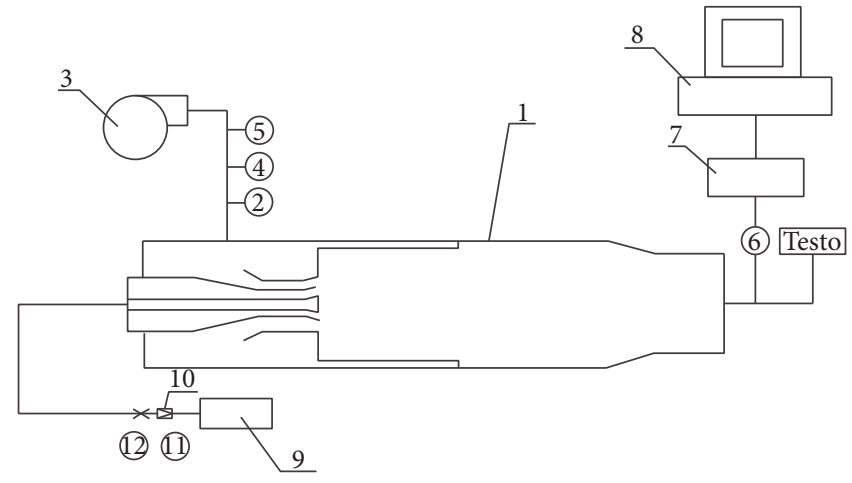

FIGURE 1: Scheme of the measurements.

combustion zone. The third airflow enters the flame tube through a number of holes. The fourth airflow enters a gap for combustor wall cooling and after passing through an external vortex generator mixes with the combustion products to reach the necessary exit afterburner temperature. The fifth stream enters channel, intended for air feeding into primary combustion zone at the region of the afterburner axis [6]. Air temperature is measured using temperature sensors 4 with an operating range of 0 to $373 \mathrm{~K}$ and pressure, manometer 5 , with an operating range of 0 to $0.15 \mathrm{MPa}$. The "Comb" of thermocouples 6 with an operating temperature range of 573 to $1573 \mathrm{~K}$ and emission analyzer Testo 350 are mounted in the outlet nozzle. The data from them via the digital converters 7 are displayed on a personal computer 8. The pilot fuel gas, required to maintain the combustion in afterburner, is supplied from the high-pressure cylinder 9 via the pressure reducing valve 10 . Simulating gas flow is controlled by Coriolis flowmeter 11 with capacity of 0 to $30 \mathrm{~g} / \mathrm{s}$ and the pressure by a vacuum gauge 12 .

The operating processes in the afterburner were studied at atmospheric pressure $(101,325 \mathrm{~Pa})$. The mass air consumption varied from 0.05 to $0.4 \mathrm{~kg} / \mathrm{s}$. Propane-butane is used as a pilot gas.

The obtained data were verified by comparison of the main afterburner parameters (consumption of the ejected air and the amount of toxic components on the exhaust) obtained by computational (using the reduced chemical mechanism) and experimental methods.
The comparisons of the calculated and experimental values of the afterburner parameters in the modes of cool (without fuel feeding and combustion) and hot (with fuel feeding and combustion) blow are shown in Figures 2 and 3 [6].

The analysis of the obtained results shows the acceptable level of coincidences of experimental and calculated values which proves the adequacy of the offered mathematical and physical model and possibility of their use for calculating the gas turbine combustors which operate on synthesis gas.

\section{Preliminary Modeling Results}

To study the influence of the synthesis gas content on the gas turbine combustor parameters using a computer-aided design system, a parameter digital model of $1 / 2$ part of a traditional diffusion-type combustor of the gas turbine engine UGT2500 [23] was designed (Figure 4). The computational grid for this part of combustor consists of 4.2 million tetrahedrons.

The calculations were performed for three variants of fuel gas content. Variant 1 provided methane supply to the combustor, the results of its calculations were compared to the results of experimental studies of a traditional diffusiontype combustor and used for verification of a kinetic scheme of hydrocarbons oxidation. Variants 2 and 3 suppose supply of synthesis gas of various content and various calorific values to the combustor (Table 3). 


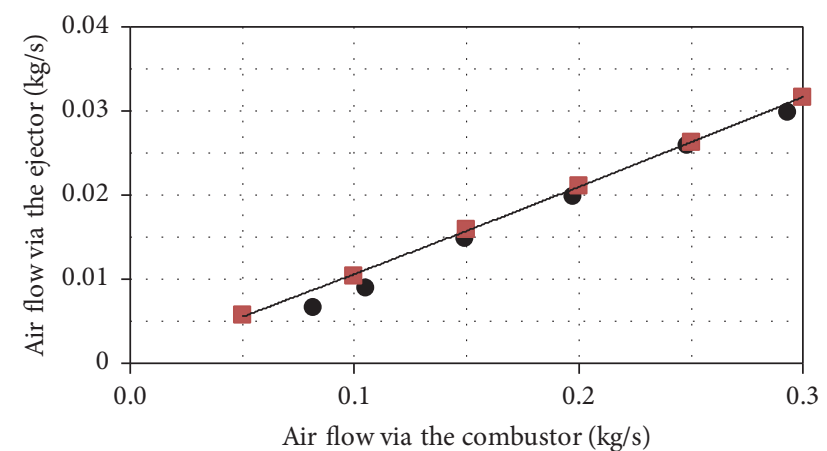

- Experiment - Calculation

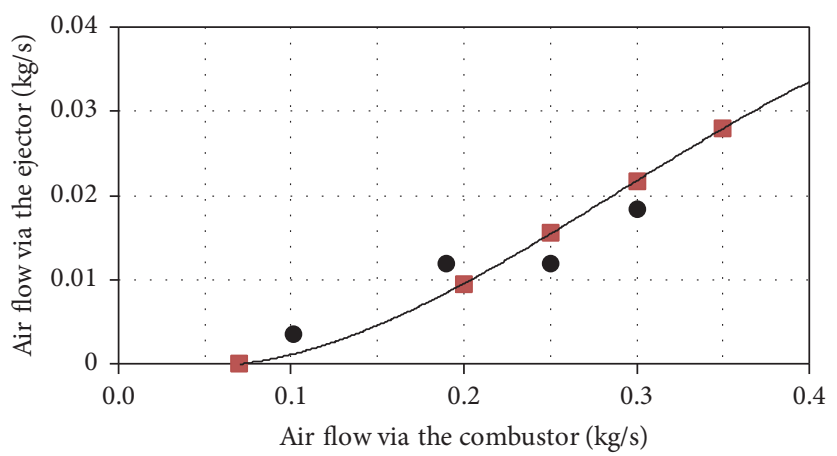

Experiment Calculation

(a)

(b)

FIGURE 2: Experimental and calculated dependence of air consumption via the ejector on air consumption via the combustor: (a) cool blow mode; (b) hot blow mode.

TABLE 3: Gas turbine combustor calculation initial data.

\begin{tabular}{|c|c|c|c|}
\hline & Variant 1 & Variant 2 & Variant 3 \\
\hline Lower calorific value, $\mathrm{kJ} / \mathrm{kg}$ & 48,800 & 21,791 & 12,448 \\
\hline \multicolumn{4}{|l|}{ Gas content, \% (vol.) } \\
\hline $\mathrm{CO}_{2}$ & 0 & 12.59 & 2.66 \\
\hline $\mathrm{H}_{2} \mathrm{O}$ & 0 & 0 & 4.88 \\
\hline $\mathrm{CO}$ & 0 & 15.09 & 59.39 \\
\hline $\mathrm{H}_{2}$ & 0 & 50.63 & 31.76 \\
\hline $\mathrm{CH}_{4}$ & 100 & 19.08 & 0 \\
\hline $\mathrm{N}_{2}$ & 0 & 2.61 & 1.31 \\
\hline $\mathrm{O}_{2}$ & 0 & 0 & 0 \\
\hline Stoichiometric air amount, $\mathrm{kg} / \mathrm{kg}$ & 16.72 & 6.70 & 3.21 \\
\hline Air flow via combustor, $\mathrm{kg} / \mathrm{s}$ & 6.91 & 6.91 & 6.91 \\
\hline Air temperature on combustor inlet, $\mathrm{K}$ & 650.0 & 650.0 & 650.0 \\
\hline Air pressure on combustor inlet, $\mathrm{MPa}$ & 11.91 & 11.91 & 11.91 \\
\hline Fuel flow via combustor, $\mathrm{kg} / \mathrm{s}$ & 0.097 & 0.217 & 0.375 \\
\hline Fuel temperature, $\mathrm{K}$ & 303 & 303 & 303 \\
\hline Total air excess coefficient & 4.26 & 4.74 & 5.74 \\
\hline Average fuel velocity in outflow holes, $\mathrm{m} / \mathrm{s}$ & 200 & 218 & 200 \\
\hline
\end{tabular}

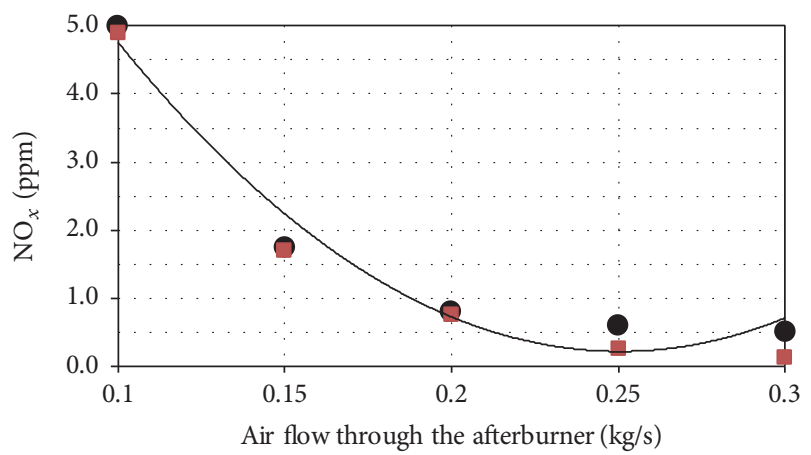

- Experiment

Calculation

Figure 3: Experimental and calculated dependence of nitrogen oxides emission on air consumption via the afterburner.
To provide the same heat power of a burning device which corresponds to the nominal mode of a GTE, the synthesis gas flows were increased in comparison to the methane flow proportionally to reduction of the lower calorific value. The areas of the flow sections of a burning device were increased which provided the required velocity of synthesis gas flow from the fuel holes without flame blow out. At this stage, apart from the change of the flow sections of a burning device no design upgrade of the combustor was made.

As a result of calculations with the use of the EDC combustion model and a simplified reduced kinetic mechanism [21] the following data on distribution of velocities, temperatures, and chemical components concentrations in the combustor were obtained.

Figure 5 shows the distribution of the velocities in the combustor. The specific growth of the flow velocity on the 


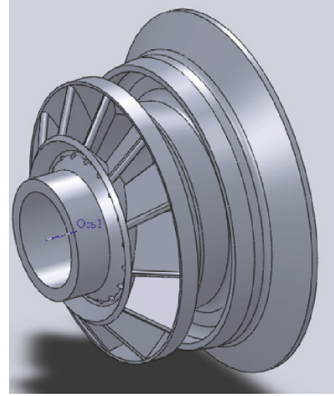

(a)

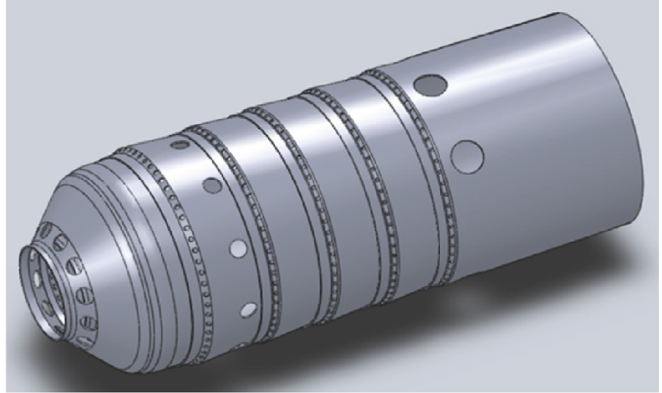

(b)

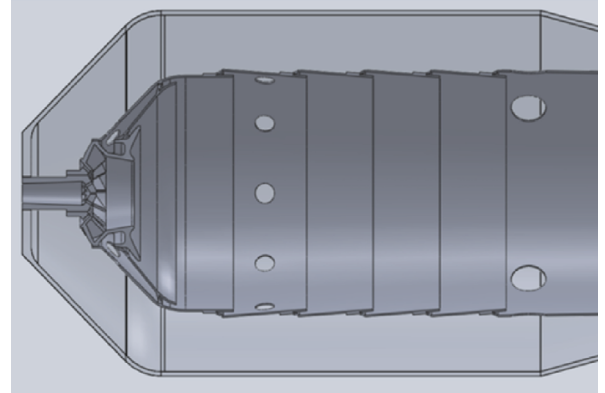

(c)

FIGURE 4: Geometry model of the combustor: (a) swirler; (b) combustion liner; (c) longitudinal section of the combustor.

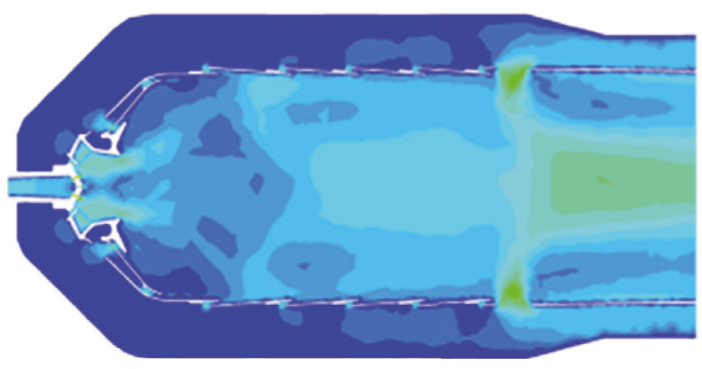

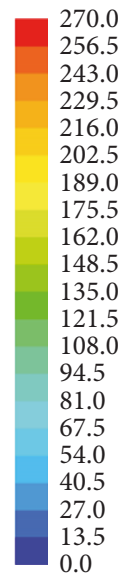

(a)

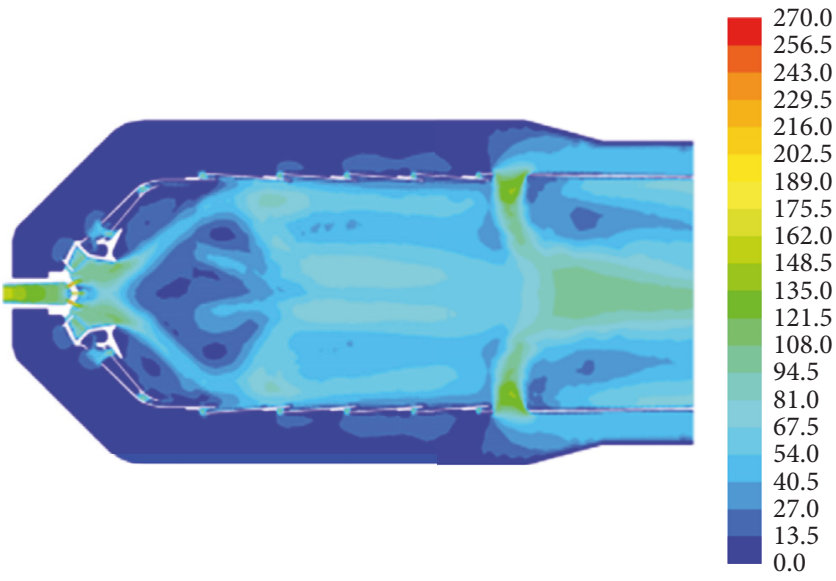

(b)

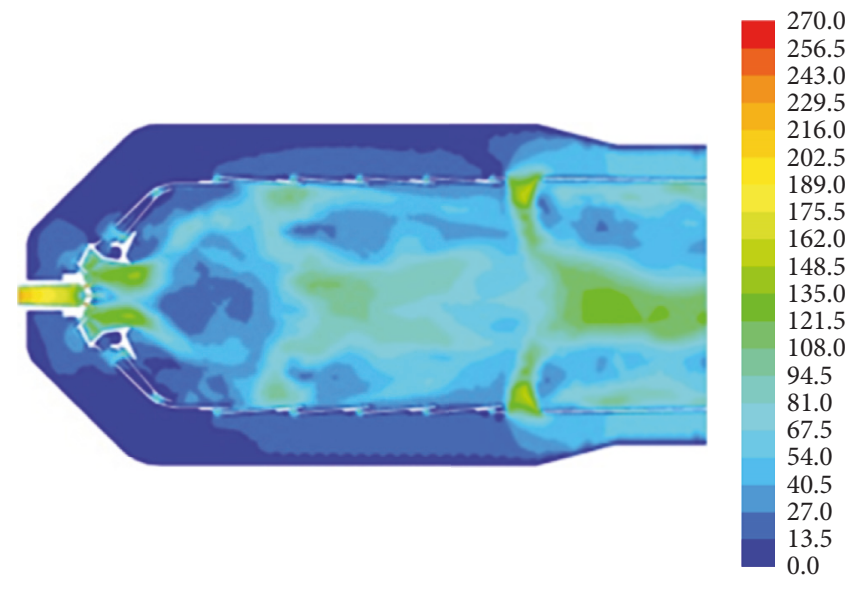

(c)

FIgURE 5: Distribution of the velocity in the longitudinal section of the combustor, $\mathrm{m} / \mathrm{s}$ : (a) variant 1; (b) variant 2; (c) variant 3.

outlet of the swirler at synthesis gas calorific value reduction is connected with corresponding growth of fuel flow.

For variant 3 the flow velocity in the area of the output section of the swirler reaches $120 \mathrm{~m} / \mathrm{s}$ when for the combustor operating on methane it is on the rational level which is about $80 \mathrm{~m} / \mathrm{s}$. This feature shows the necessity of changing open flow areas in the swirler to provide the calculated velocities in the combustion zone during combustor modification.
It is possible to analyze the details of the changing character of the working medium velocities using Figure 6 where the distribution of the axial velocity component in the longitudinal combustor section is shown. Variants 1 and 2 show the presence of the stable symmetry zone of reverse flows which stabilize combustion. In variant 3 (with the lowest calorific value of synthesis gas) the reverse flows zone is much more diluted which determines lower stabilizing action 


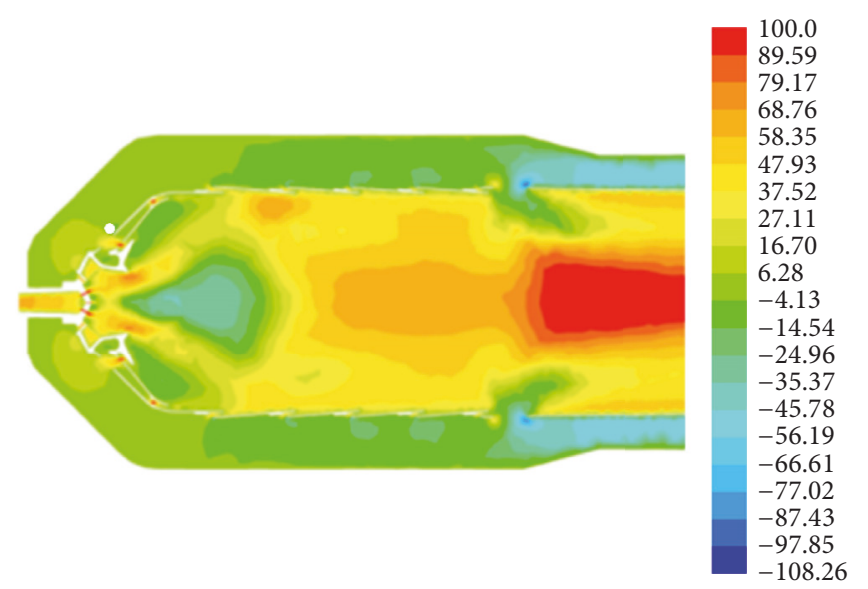

(a)

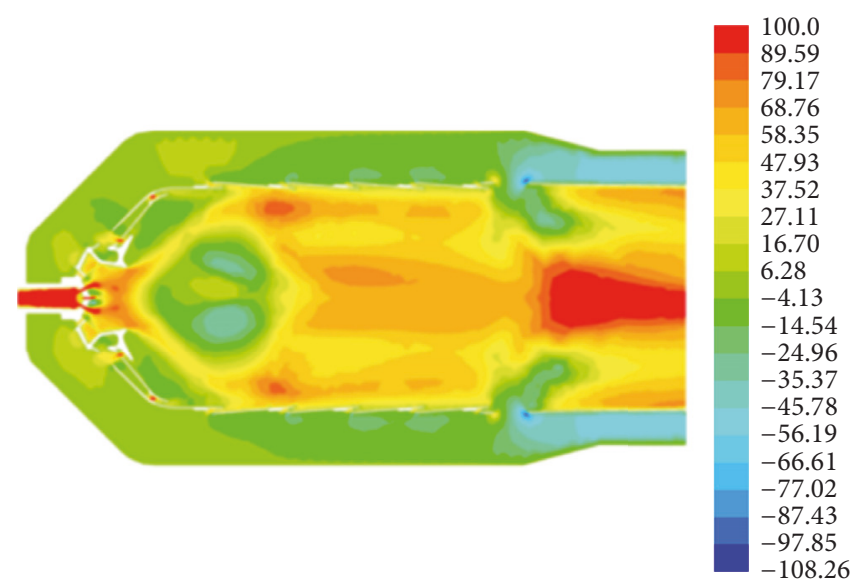

(b)

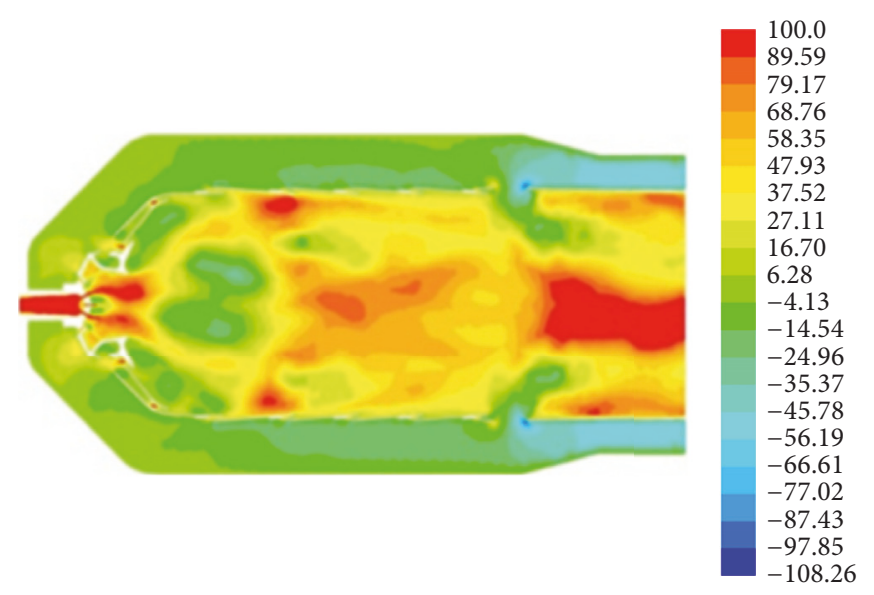

(c)

FIGURE 6: Distribution of the axial velocity component in the longitudinal section, m/s: (a) variant 1; (b) variant 2; (c) variant 3.

of the combustion products. It should be mentioned that for variant 3 the asymmetry of the flows in the combustion liner starts appearing which indirectly proves lower stability of the flame in comparison to variants 1 and 2 .

Figures 7 and 8 show the diagrams of the dependence of average mass temperature along the combustor and the temperature contours in the combustion liner. As the fuel gas calorific value decreases, the combustion zone moves away from the burning device and shifts to the combustion liner outlet. Asymmetry of the temperature field for variant 3 with the lowest calorific value of synthesis gas shows combustion nonstability which requires development of the actions to improve the efficiency of the flame front stabilization. The presence of methane in synthesis gas content (variant 2) stabilizes temperature distribution.

There is no decrease of the maximum temperature in the combustor volume in connection with decrease of the fuel gas calorific value as the diffusion burning principle is implemented in the considered gas turbine combustor.

Distribution of carbon oxide CO in the combustion liner is shown in Figure 9. The growth of the $\mathrm{CO}$ maximum concentration in the primary combustor zone from variant 1 to variant 3 is logical as the initial total carbon mass flow in the

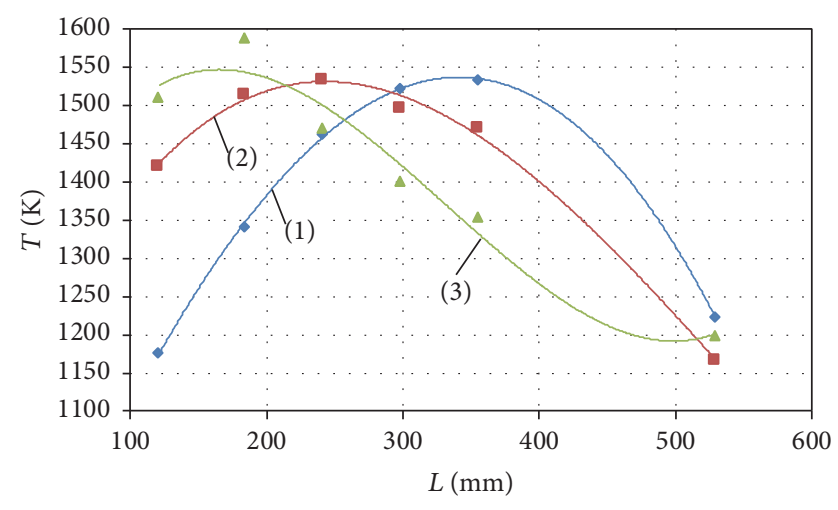

(1) Low calorific value $=48,800 \mathrm{~kJ} / \mathrm{kg}$

(2) Low calorific value $=21,791 \mathrm{~kJ} / \mathrm{kg}$

(3) Low calorific value $=12,448 \mathrm{~kJ} / \mathrm{kg}$

FIGURE 7: Change of average mass temperature $(T)$ along the length $(L)$ of the combustor.

fuel gas for variant 3 is maximum. In general, in comparison to variant 1 the mole fraction of $\mathrm{CO}$ on the output for variant 2 decreased by $44.3 \%$ and for variant 3 by $50 \%$. 


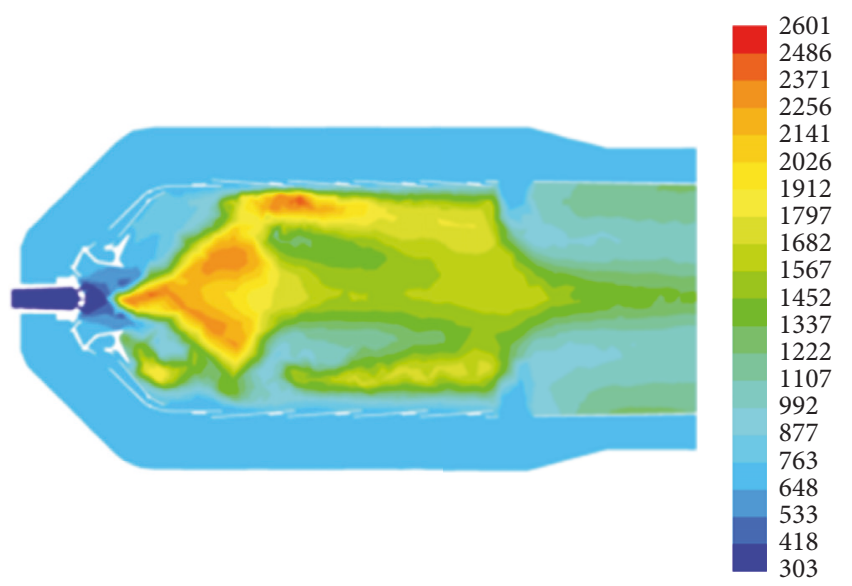

(a)

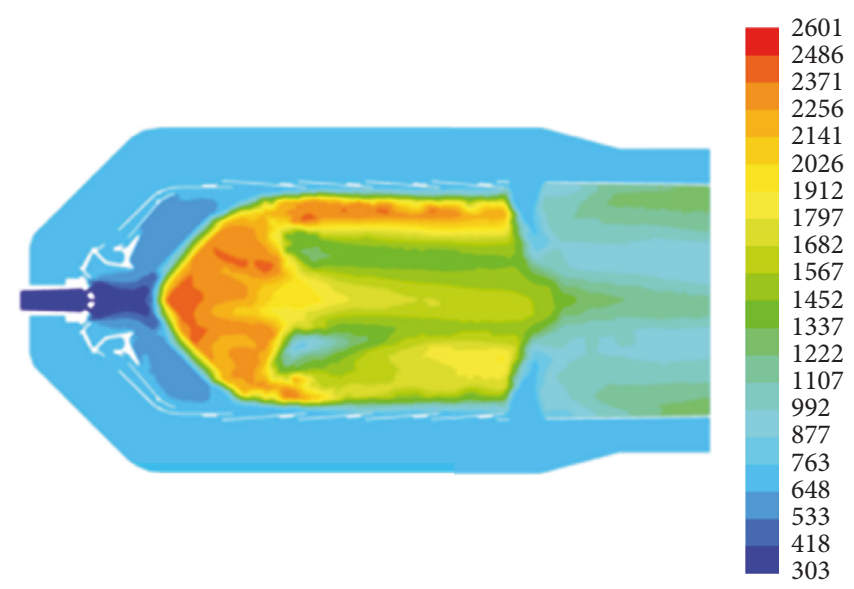

(b)

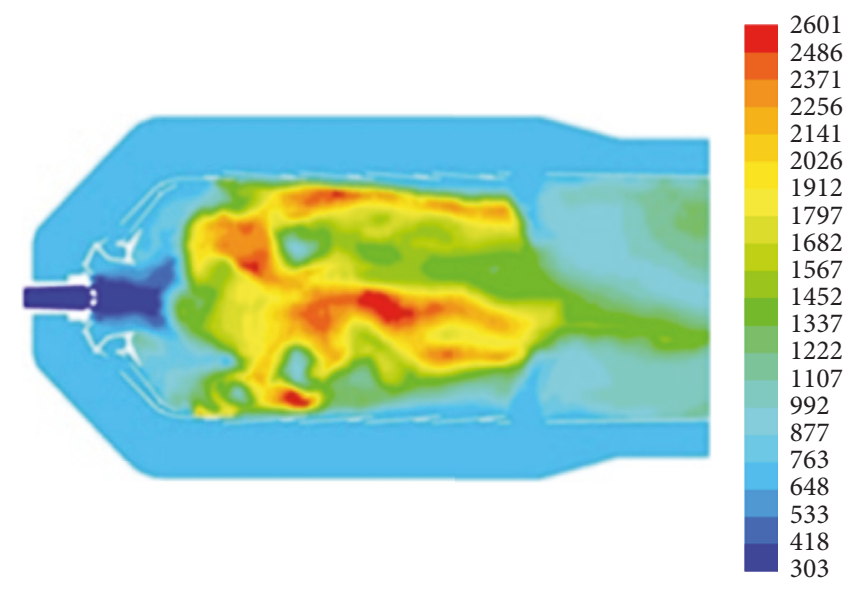

(c)

FIGURE 8: Temperature contours in the longitudinal section of the combustor, K: (a) variant 1; (b) variant 2; (c) variant 3.

Nevertheless, considering the obtained data, it is possible to stipulate that the growth of the combustion volume is positive for the level of $\mathrm{CO}$ burning off and the combustion efficiency.

Figure 10 shows distribution of nitrogen oxides in the combustor. With the decrease of the synthesis gas calorific value and increase of the velocity of gases flow in the combustor the zone of NO formation shifts to the outlet section. Thus, the NO emission for variant 3 with the minimum synthesis gas calorific value is about $200 \mathrm{ppm}$. Nitrogen oxides emission of the combustor which operates on synthesis gas which contains methane (variant 2) is $94 \mathrm{ppm}$. The calculated emission of nitrogen oxides in the combustor which operates on methane (variant 1 ) is $66 \mathrm{ppm}$.

It should be mentioned that air redistribution along the combustion liner at further combustor modification will allow avoiding the local values of the air excess coefficient at which nitrogen oxides emission is maximum and reducing the volume of the zones of possible nitrogen oxides formation.

The results of the performed three-dimension CFD calculations are shown in Table 4. The total pressure losses in the combustor were defined too.
At calculating a gas turbine unit cycle it was determined that the average temperature on the turbine outlet of the GTE with the power of $2.5 \mathrm{MW}$ operating on natural gas is $740 \mathrm{~K}$ (that corresponds to the experimental data $733 \mathrm{~K}$ [23]), and the maximum temperature in the combustion zone is $2,363 \mathrm{~K}$. Thus, the applied mathematical model with the simplified reduced mechanism $[20,21]$ allows adequately predicting the temperature parameters of the combustor.

Unlike natural gas which has been used over many years and for which much combustion data is collected, synthesis gas fuel mixtures and their kinetics have not been widely investigated [24].

Therefore the investigation of the influence of kinetic schemes on parameter distribution in the volume of the gas turbine combustor operating on synthesis gas with minimum low calorific value (variant 3 ) was performed. Two detailed mechanisms of chemical kinetics were used for comparative calculations: mechanism 1 simplified 35-reaction reduced mechanism [20, 21] and mechanism 2 70-reaction mechanism [22] developed for modeling of combustion of fuels which do not contain methane.

The results of modeling are shown in Table 5 and Figures 11 and 12 . 


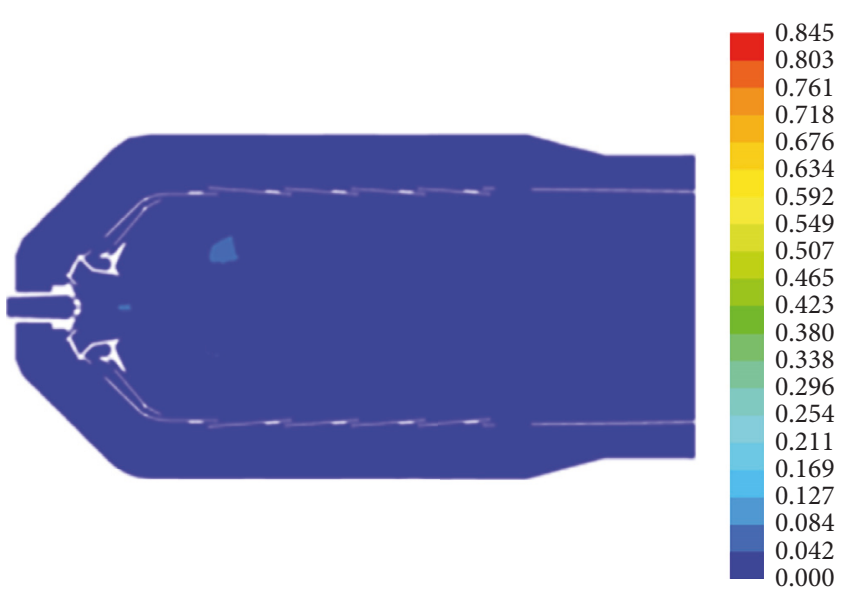

(a)

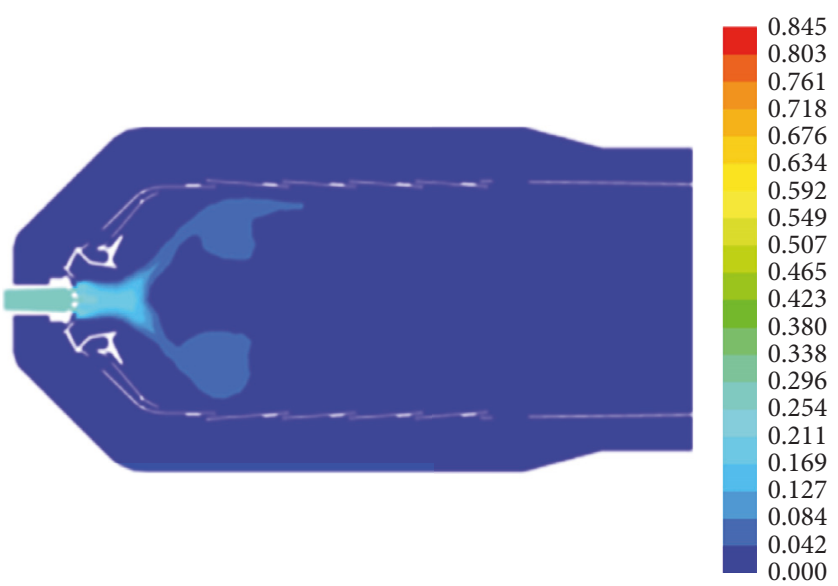

(b)

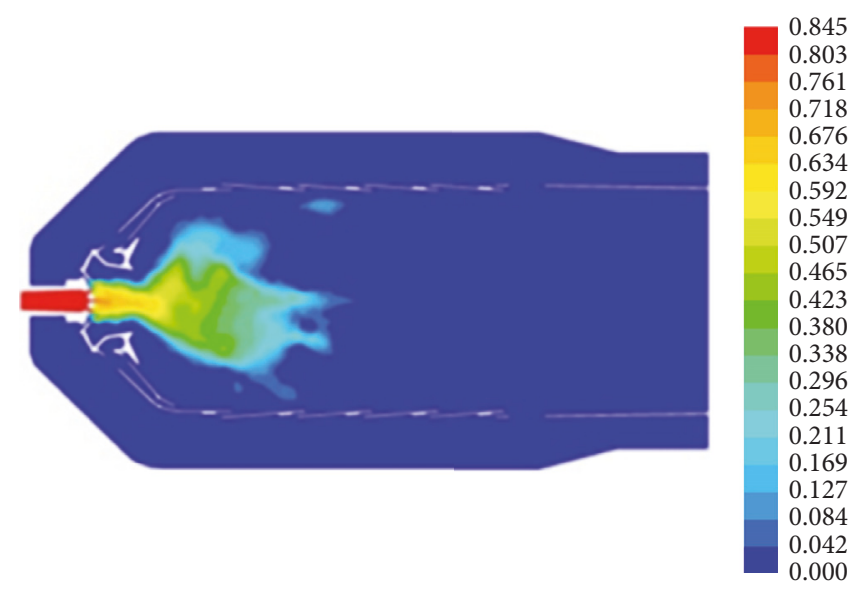

(c)

FIGURE 9: Distribution of CO mass fractions in the longitudinal section of the combustor: (a) variant 1; (b) variant 2; (c) variant 3.

TABLE 4: Results of combustor calculations.

\begin{tabular}{lccc}
\hline & Variant 1 & Variant 2 & Variant 3 \\
\hline Low calorific value, $\mathrm{kJ} / \mathrm{kg}$ & 48,800 & 21,791 & 12,448 \\
Temperature on combustor outlet, $\mathrm{K}$ & 1,224 & 1,167 & 74.56 \\
Velocity on combustor outlet, $\mathrm{m} / \mathrm{s}$ & 74.18 & 0.00022 & 0 \\
Mole fraction of $\mathrm{CH}_{4}$ & 0.00042 & 0.1604 & 0.35 \\
Mole fraction of $\mathrm{O}_{2}$ & 0.1544 & 0.0261 & 0.1631 \\
Mole fraction of $\mathrm{CO}_{2}$ & 0.0235 & 0.051 & 0.0508 \\
Mole fraction of $\mathrm{H}_{2} \mathrm{O}$ & 0.0501 & 0.260 & 0.0304 \\
Content of $\mathrm{N}_{2} \mathrm{O}, \mathrm{ppm}$ & 0.363 & 94.0 & 0.0393 \\
Content of $\mathrm{NO}, \mathrm{ppm}$ & 65.7 & 4.31 & 200.3 \\
Total pressure losses, $\%$ & 4.51 & & 4.03 \\
\hline
\end{tabular}

The results of the calculations show that there is no significant difference in contours of the velocities at using both mechanisms (Figure 11). The temperature fields also do not have significant differences (Figure 12). Distribution of the concentrations of all the chemical components of the oxidation scheme has similar nature.
Thus, we can recommend both considered kinetic mechanisms for defining the main parameters of the combustor operating on synthesis gas.

It should be mentioned that emission parameters of the series production combustor of the GTE with the power of $2.5 \mathrm{MW}$ [23] due to its conversion from natural gas to 
TABLE 5: Calculation results for combustor using various chemical kinetics mechanisms.

\begin{tabular}{lcc}
\hline & Mechanism 1 & Mechanism 2 \\
\hline Low calorific value, $\mathrm{kJ} / \mathrm{kg}$ & 12,448 & 12,448 \\
Temperature on combustor outlet, $\mathrm{K}$ & 1,199 & 1,150 \\
Velocity on combustor outlet, $\mathrm{m} / \mathrm{s}$ & 81.35 & 79.98 \\
Mole fraction of $\mathrm{CH}_{4}$ & 0 & 0 \\
Mole fraction of $\mathrm{O}_{2}$ & 0.1631 & 0.1665 \\
Mole fraction of $\mathrm{CO}_{2}$ & 0.0508 & 0.0457 \\
Mole fraction of $\mathrm{H}_{2} \mathrm{O}$ & 0.0304 & 0.0276 \\
\hline
\end{tabular}

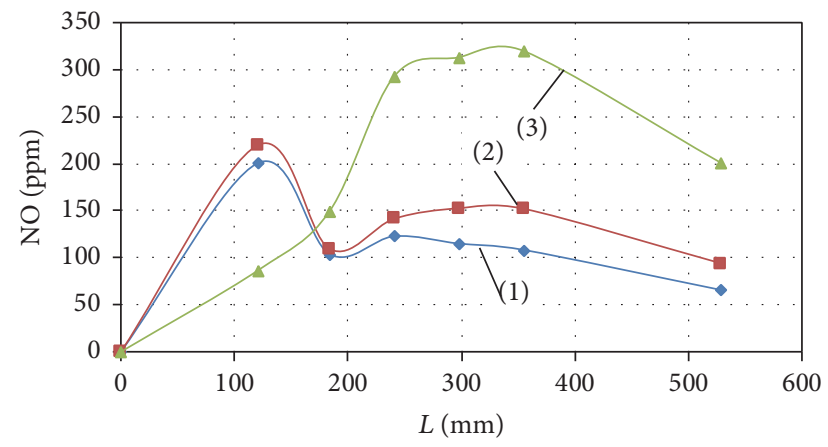

(1) Low calorific value $=48,800 \mathrm{~kJ} / \mathrm{kg}$

(2) Low calorific value $=21,791 \mathrm{~kJ} / \mathrm{kg}$

(3) Low calorific value $=12,448 \mathrm{~kJ} / \mathrm{kg}$

Figure 10: Distribution of NO volume fractions in the longitudinal sections of the combustor.

synthesis gas without design changes of the main elements (e.g., a combustion liner) are unsatisfying in terms of modern requirements to the toxic components emission. Thus, there should be development of the effective arrangements connected with using of prospective schemes of synthesis gas combustion organization.

\section{Upgrade of Working Process in Gas Turbine Combustor Operating on Synthesis Gas: Results and Discussion}

Numerical study of the $2.5 \mathrm{MW}$ gas turbine combustor showed the necessity to provide significant changes to the scheme of the combustor working process organization in order to increase stability and efficiency of its operation especially when operating on low calorific synthesis gas. Simple replacement of natural gas (methane) with synthesis gas for a series produced gas turbine combustor leads to increase of toxic components emission, particularly nitrogen oxides.

To improve the series produced UGT2500 combustor [23] parameters the numerical calculations of its modifications were performed aimed at selection of rational geometry and mode parameters of a prospective two-zone combustor.

Initially, the following changes were made in the series produced combustor design: (i) The amount of air supplied to the primary zone of combustion was reduced due to shifting from a barrier cooling system to a convective one and formation of an RQL scheme of synthetic fuel combustion.

(ii) The air swirler was moved beyond the combustion liner and the form of the primary combustion zone was changed to the conic one.

(iii) Special plugs (shells) were added to the primary air holes to increase the depth of entering of air flows and improve the quality of components mixing on the output.

To reduce the possibility of formation of local areas in the combustor with the stoichiometric value of the air excess coefficient and reduction of air suctions to the primary zone (Rich-Burn) it is offered to pinch the section of the combustion liner before the holes of primary air supply.

For modified designs 1 and 2 the diameter of the corresponding shell ring of the combustion liner was reduced by $10 \%$ (Figure 13(a)) and by 55\% (Figure 13(b)) in comparison with basic design. For design 2 the decision was made not to change the form and size of the combustor casing in order to minimize the structure changes of the basic construction. Higher pinching of the combustion liner section in this case allowed avoiding installation of special plugs for increasing of primary air jets penetration.

The graph dependence shows the minimum air suction to the side of the swirler in design 2 (Figure 14(b)). It was favorable for reduction of the maximum temperature in the primary combustion zone which decreased from $2,400 \mathrm{~K}$ to $2,150 \mathrm{~K}$ for modified design 2 (Figure 15(b)).

Despite this, in the output section of the combustion liner there is no significant increase of carbon oxide emission (Figure 16). The change of the areas of the ring shells flow sections (at shifting from the rich air-fuel mixture combustion zone to the quick mixing zone) additionally provides slowdown of the flow and more qualitative mixing of air-fuel mixture with an additional oxidant.

The obvious effect of lack of primary air suction to the rich air-fuel mixture combustion zone is sharp decrease of the calculated concentrations of nitrogen oxides in the outlet section to $29 \mathrm{ppm}$ for modified design 2 (Figure 17(b) and Table 6) which corresponds to modern environmental requirements. There are almost no local areas of thermal nitrogen oxides formation in the primary combustion zone for design 2. This effect is possible due to provision of rational 


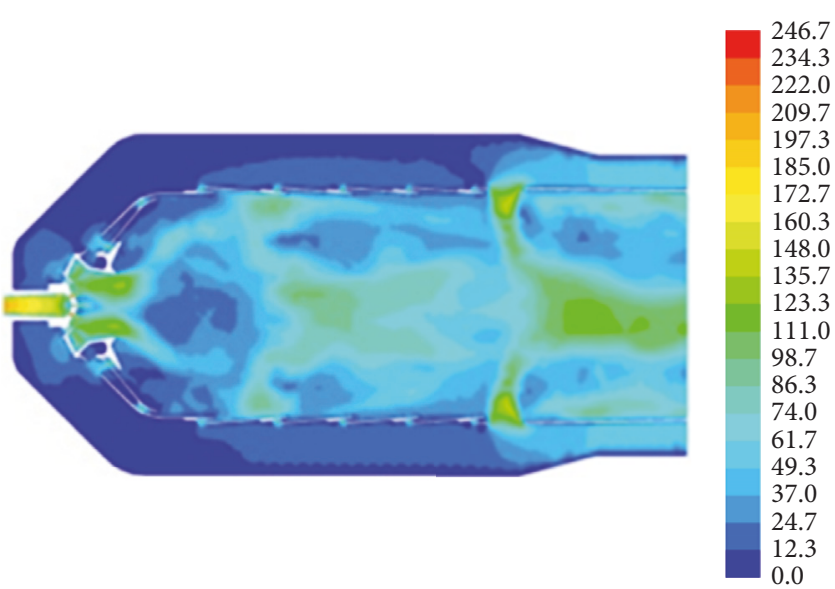

(a)

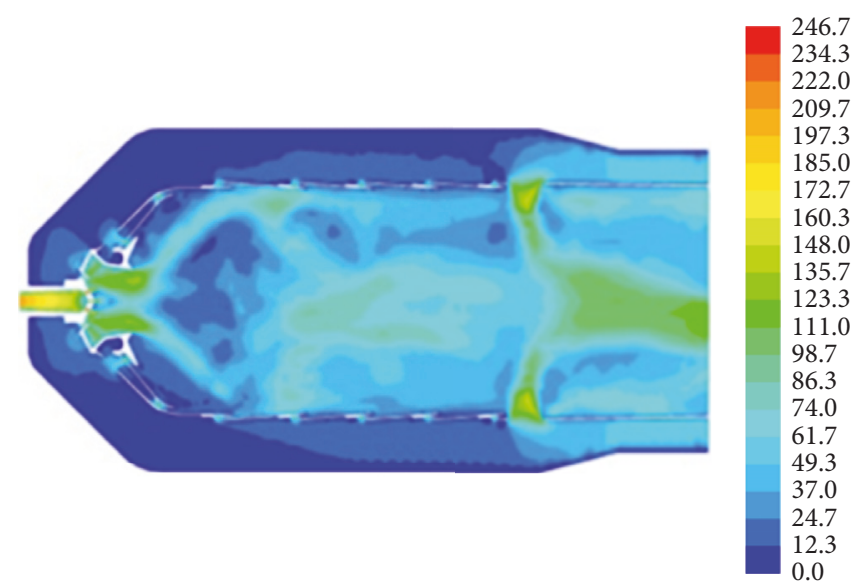

(b)

FIGURE 11: Distribution of the velocities in the longitudinal section of the combustor, m/s: (a) mechanism 1; (b) mechanism 2.

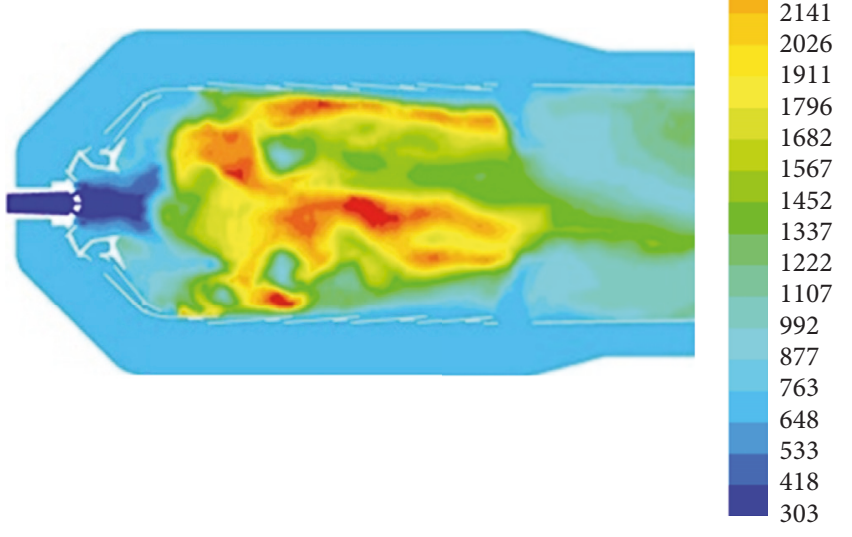

(a)

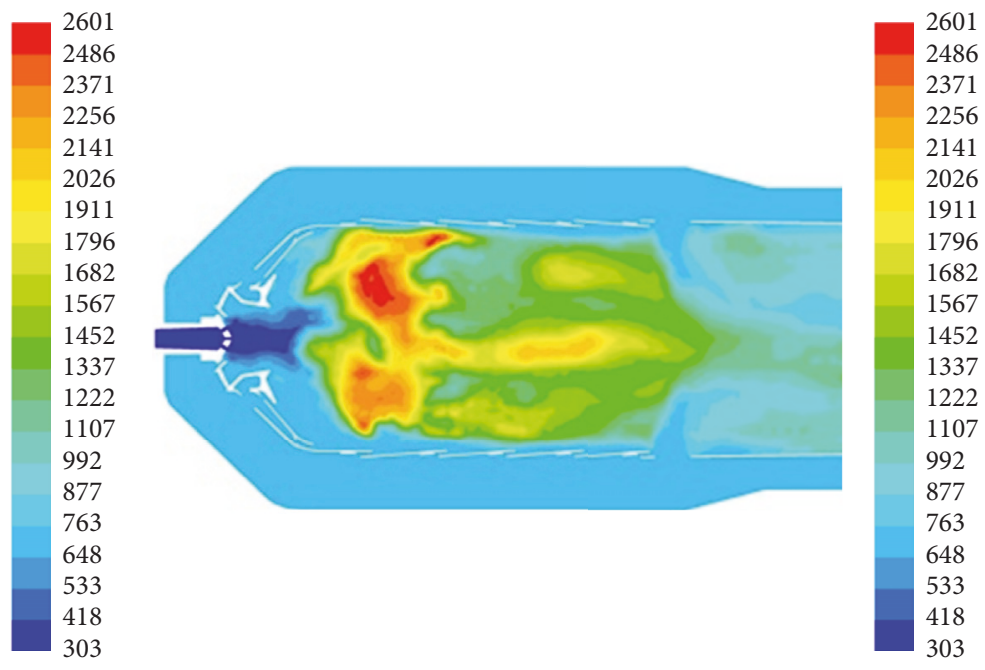

(b)

FIGURE 12: Temperature field in the longitudinal section of the combustor, K: (a) mechanism 1; (b) mechanism 2.

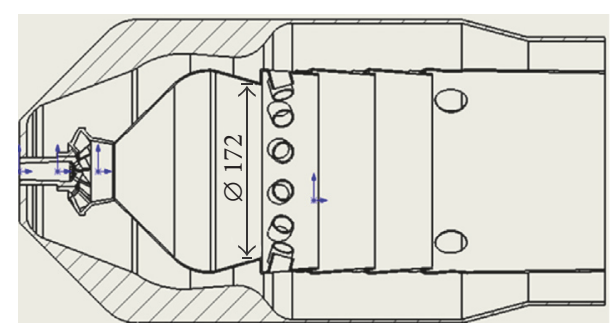

(a)

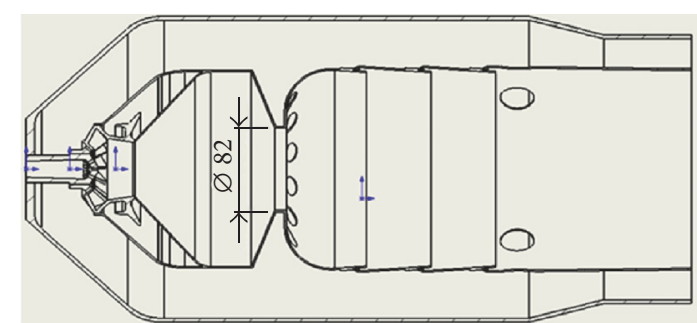

(b)

FIGURE 13: Structure designs of combustors: (a) modified design 1; (b) modified design 2.

values of the air excess coefficients in the sections of the combustion liner. In the primary zone it was 0.54 and 2.4-2.6 in the secondary zone.

Figure 18 presents the dependencies of $\mathrm{NO}$ concentration in the outlet combustor section on the ratio of the diameter of the reduced ring shell part $\left(d_{1}\right)$ to the diameter of the cylinder part $\left(d_{0}\right)$ of the combustion liner. With decrease of this ratio emission of nitric oxide is decreased too.

As at operation of the gas turbine combustor on synthetic fuel (to provide its constant heat capacity) the synthesis gas 
TABLE 6: Results of modeling of modified combustor designs operating on synthesis gas.

\begin{tabular}{lcc}
\hline & Design 1 & Design 2 \\
\hline Temperature on the combustor outlet, $\mathrm{K}$ & 1,192 & 1,190 \\
Velocity on combustor outlet, $\mathrm{m} / \mathrm{s}$ & 82.02 & 75.00 \\
Mole fraction of $\mathrm{CH}_{4}$ & 0.000001 & 0.00001 \\
Mole fraction of $\mathrm{O}_{2}$ & 0.1582 & 0.1577 \\
Mole fraction of $\mathrm{CO}_{2}$ & 0.0277 & 0.0276 \\
Mole fraction of $\mathrm{H}_{2} \mathrm{O}$ & 0.0537 & 0.0544 \\
Content of $\mathrm{N}_{2} \mathrm{O}, \mathrm{ppm}$ & 0.173 & 0.225 \\
Content of $\mathrm{NO}, \mathrm{ppm}$ & 109.1 & 28.9 \\
\hline
\end{tabular}

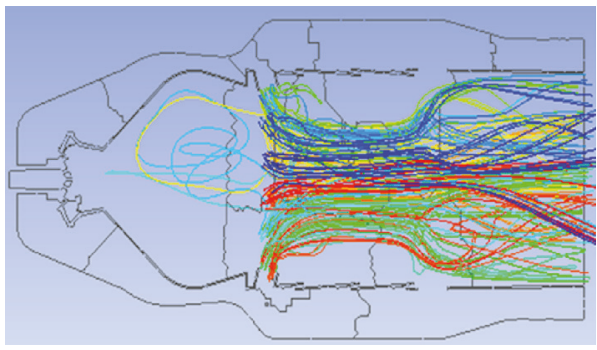

(a)

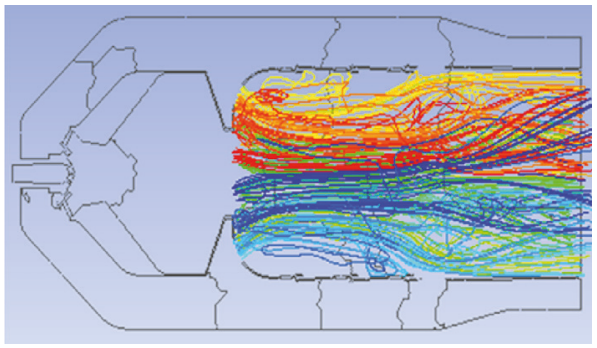

(b)

FIGURE 14: Lines of the air tracks of the quick mixing (Quick-Mix) zone: (a) modified design 1; (b) modified design 2.

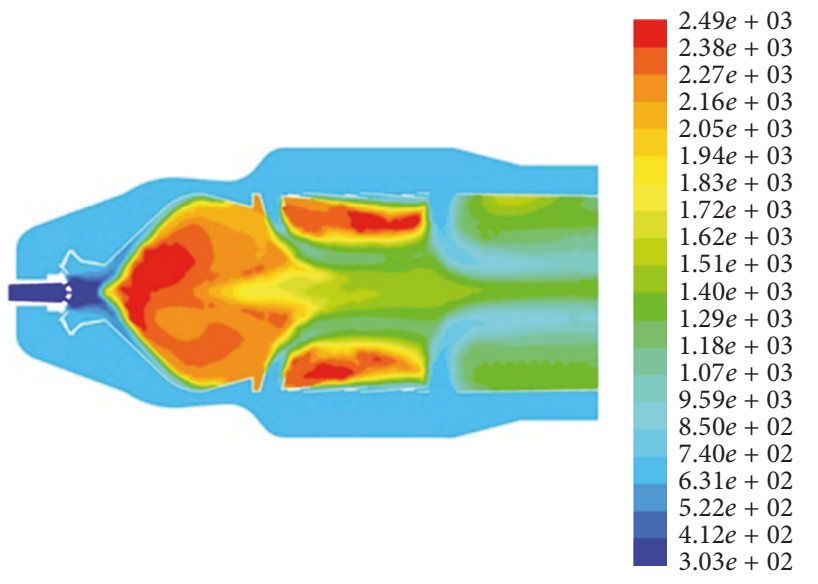

(a)

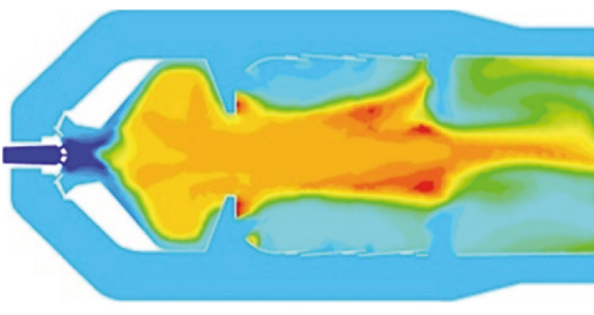

(b)

FIGURE 15: Temperature field in the longitudinal section of the combustor, K: (a) modified design 1; (b) modified design 2.

flow grows to a high rate in comparison to the natural gas flow, there is practical interest for the interval of the values of the synthesis gas calorific value which allows implementing its stable and effective burning off without additional supply of natural gas.

The given variant calculations supposed supply of synthesis gas of various content and calorific value obtained by plasma treatment of low grade coal $[2,5]$ to the combustor of modified design 2, which has been chosen as the burning device with the minimal NO emission level: case 1: lower calorific value of synthesis gas, $33,089 \mathrm{~kJ} / \mathrm{kg}$, case 2 : $21,791 \mathrm{~kJ} / \mathrm{kg}$, and case $3: 12,448 \mathrm{~kJ} / \mathrm{kg}$.
The data of three-dimension CFD calculations (Table 7 and Figure 19) performed using the simplified reduced mechanism show that when a combustor of the 2.5 MW GTE operates on synthesis fuel, the minimum value of the synthesis gas low calorific value which provides its effective burning off without additional supply of natural gas is about $20 \mathrm{MJ} / \mathrm{kg}$.

Increase of the values of the maximum temperature in the combustion zone (Figure 19(b)) and the temperature on the combustor outlet for synthesis gas with the minimum low calorific value (case 3 ) is explained by significant increase of fuel gas flow rate, its outflow velocity from the burning device, and the change of the aerodynamic structure of the reacting 
TABLE 7: Calculation results of the combustor which operates on various-content synthesis gas.

\begin{tabular}{lccc}
\hline & Case 1 & Case 2 & Case 3 \\
\hline Low calorific value, $\mathrm{kJ} / \mathrm{kg}$ & 33,089 & 21,791 & 12,448 \\
Temperature on the combustor outlet, $\mathrm{K}$ & 1,182 & 1,191 & 1,300 \\
NO content on the outlet, ppm & 31.4 & 28.9 & 116.4 \\
Total pressure losses, $\%$ & 4.72 & 4.71 & 3.87 \\
\hline
\end{tabular}

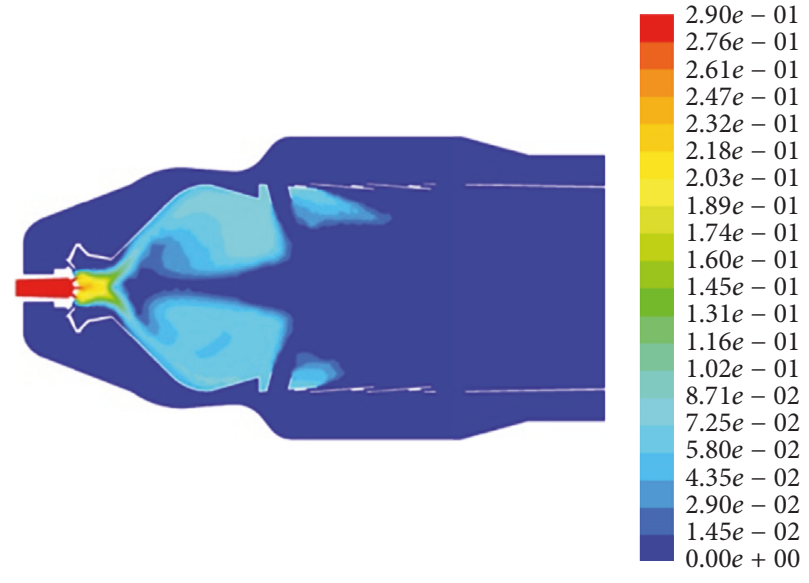

(a)

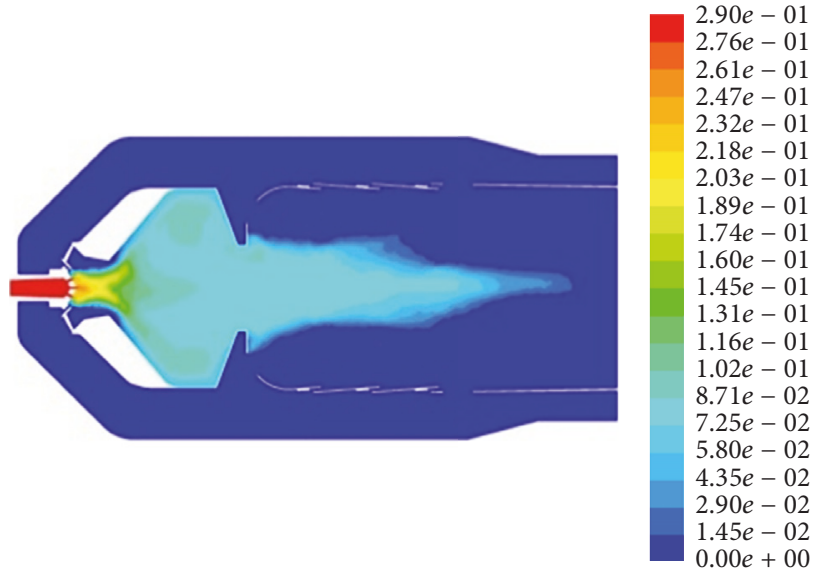

(b)

FIGURE 16: Distribution of CO mass fractions in the longitudinal sections of the combustor: (a) modified design 1; (b) modified design 2.

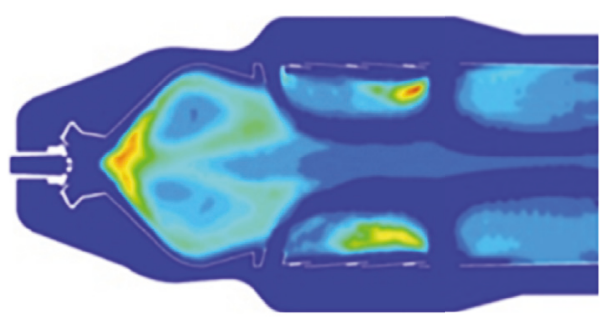

(a)

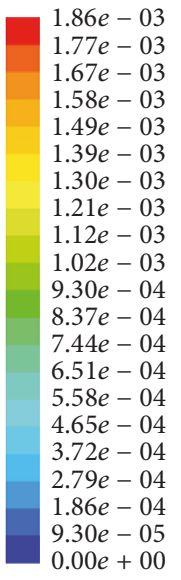

00

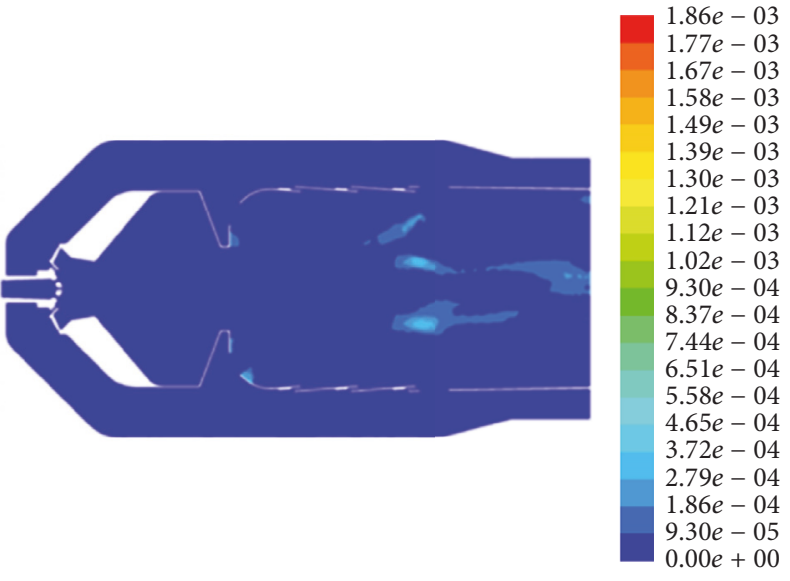

(b)

FIGURE 17: Distribution of NO mass fractions in the longitudinal sections of the combustor: (a) modified design 1; (b) modified design 2.

flows which leads to worsening of the combustor ecological parameters.

\section{Conclusions}

Theoretical investigations of the gas turbine combustor operating on the synthesis gas are performed. Numerical study showed the necessity to provide significant changes to the scheme of the combustor working process organization in order to increase stability and efficiency of its operation especially when operating on low calorific synthesis gas. To improve the characteristics of the GTE combustor operating on synthesis gas use of promising RQL combustion technology is proposed. The three-dimensional mathematical model and different kinetic mechanisms of a synthesis gas combustion processing have been used for enhancement of the 2.5 MW gas turbine ecological parameters. The application of the practical recommendations can reduce the nitrogen oxides emission up to $29 \mathrm{ppm}$ in the exit section of the 


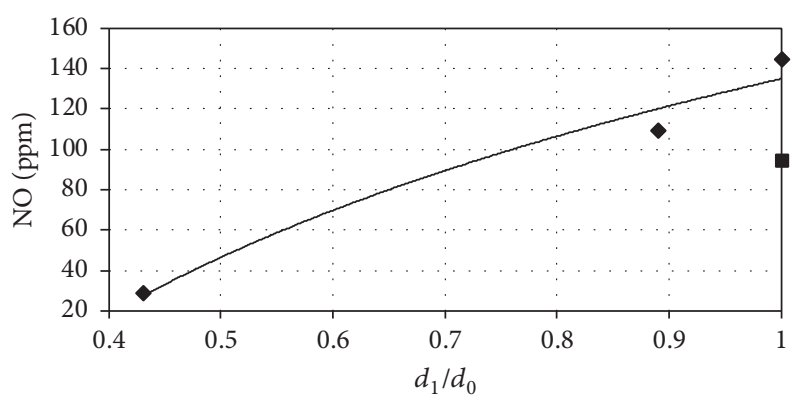

- NO mole fraction for modified designs

- NO mole fraction for the basic design

FIGURE 18: Emission of nitrogen oxides NO in the combustor operating on synthesis gas.

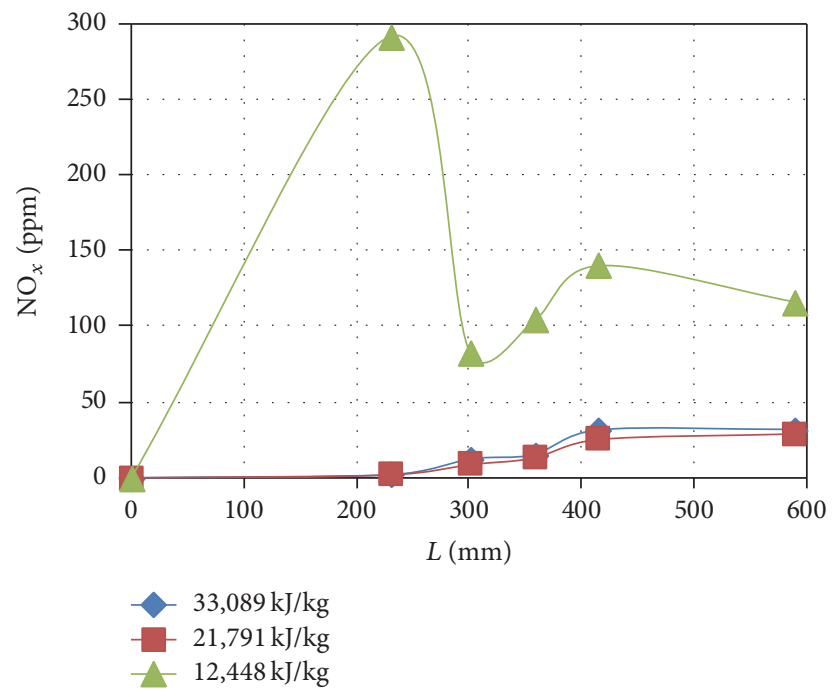

(a)

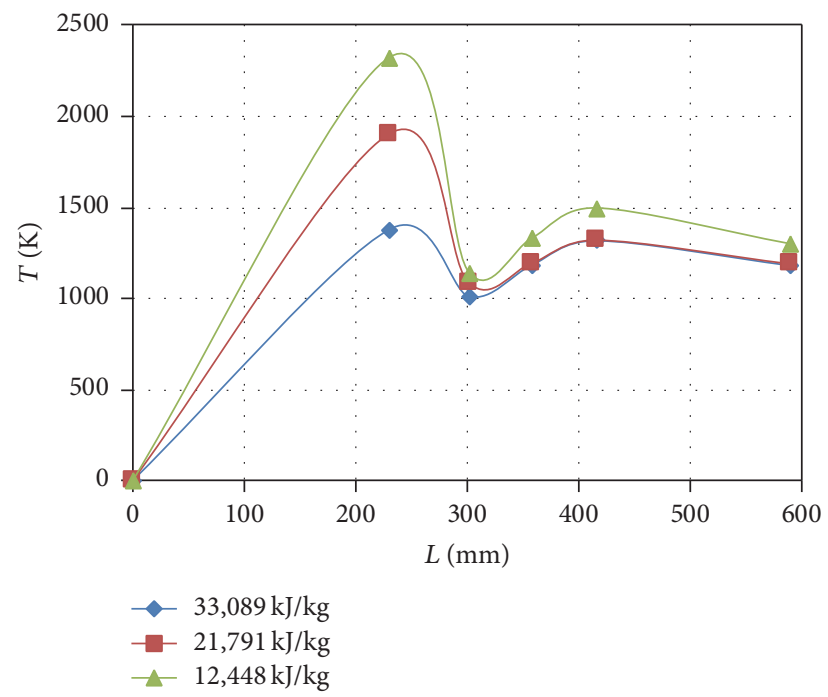

(b)

FIGURE 19: Combustor characteristics: (a) change of the nitrogen oxides emission; (b) change of average temperature along the combustor which operates on various content synthesis gas. gas turbine combustors working on synthesis gas which are developed.

\section{Conflicts of Interest}

The authors have no conflicts of interest related to the conduct and reporting of this research.

\section{References}

[1] S. Gadde, J. Xia, and G. McQuiggan, Advanced F Class Gas Turbines Can Be a Reliable Choice for IGCC Applications, Siemens Power Generation Inc, 2006.

[2] I. B. Matveev, N. V. Washcilenko, S. I. Serbin, and N. A. Goncharova, "Integrated plasma coal gasification power plant," IEEE Transactions on Plasma Science, vol. 41, no. 12, pp. 31953200, 2013.

[3] I. B. Matveev, S. I. Serbin, and N. V. Washchilenko, "Sewage sludge-to-power," IEEE Transactions on Plasma Science, vol. 42, no. 12, pp. 3876-3880, 2014.

[4] S. I. Serbin, I. B. Matveev, and N. A. Goncharova, "Plasmaassisted reforming of natural gas for GTL. Part I," IEEE Transactions on Plasma Science, vol. 42, no. 12, pp. 3896-3900, 2014.

[5] I. B. Matveev, N. V. Washchilenko, and S. I. Serbin, "Plasmaassisted reforming of natural gas for GTL: part III_-gas turbine integrated GTL," IEEE Transactions on Plasma Science, vol. 43, no. 12, pp. 3969-3973, 2015.

[6] I. B. Matveev, S. I. Serbin, V. V. Vilkul, and N. A. Goncharova, "Synthesis gas afterburner based on an injector type plasmaassisted combustion system," IEEE Transactions on Plasma Science, vol. 43, no. 12, pp. 3974-3978, 2015.

[7] S. I. Serbin, I. B. Matveev, and G. B. Mostipanenko, "Investigations of the working process in a 'lean-burn' gas turbine combustor with plasma assistance," IEEE Transactions on Plasma Science, vol. 39, no. 12, pp. 3331-3335, 2011.

[8] I. Matveev and S. Serbin, "Investigation of a reverse-vortex plasma assisted combustion system," in Proceedings of the ASME 2012 Heat Transfer Summer Conference, HT2012-58037, pp. 133140, Rio Grande, Puerto Rico, USA, July 2012.

[9] V. E. Messerle, E. I. Karpenko, A. B. Ustimenko, and O. A. Lavrichshev, "Plasma preparation of coal to combustion in power boilers," Fuel Processing Technology, vol. 107, pp. 93-98, 2013.

[10] V. E. Messerle, A. B. Ustimenko, and O. A. Lavrichshev, "Comparative study of coal plasma gasification: simulation and experiment," Fuel, vol. 164, pp. 172-179, 2016.

[11] H. J. Jung and E. R. Becker, "Emission control for gas turbines," Platinum Metals Review, vol. 31, no. 4, pp. 162-170, 1987.

[12] A. H. Lefebvre and D. R. Ballal, Gas Turbine Combustion: Alternative Fuels and Emissions, Taylor \& Francis, 2010.

[13] Rich burn, quick-mix, lean burn (RQL) combustor, http://www .netl.doe.gov/File\%20Library/Research/Coal/energy\%20systems/turbines/handbook/3-2-1-3.pdf.

[14] M. Welch and B. Igoe, "An introduction to combustion, fuels, emissions, fuel contamination and storage for industrial gas turbines," in Proceedings of the ASME Turbo Expo 2015: Turbine Technical Conference and Exposition (GT '15), Montreal, Canada, June 2015.

[15] P. E. Rokke, J. E. Hustad, N. A. Rokke, and O. B. Svendsgaard, "Technology update on gas turbine dual fuel, dry low emission combustion systems," ASME GT2003-38112, 2003. 
[16] J. D. Willis and A. J. Moran, "Industrial RB211 DLE gas turbine combustion update," ASME 2000-GT-0109, 2000.

[17] "The Generalized Finite-Rate Formulation for Reaction Modeling," https://www.sharcnet.ca/Software/Ansys/16.2.3/en-us/ help/flu_th/flu_th_sect_finite_rate.html.

[18] V. G. McDonell, "Key Combustion Issues Associated with Syngas and High-Hydrogen Fuels," https://www.netl.doe.gov/ File\%20Library/Research/Coal/energy\%20systems/turbines/ handbook/3-1.pdf.

[19] A. de Pascale, M. Fussi, and A. Peretto, "Numerical simulation of biomass derived syngas combustion in a swirl flame combustor," ASME, GT-2010-22791, 2010.

[20] S. I. Serbin and N. A. Goncharova, "The characteristics of 2.5 MW gas turbine combustor working on synthesis gas," Aerospace Technic and Technology, vol. 7, no. 94, pp. 119-123, 2012 (Russian).

[21] An optimized detailed chemical reaction mechanism for methane combustion GRI-Mech 3.0, http://www.me.berkeley .edu/gri_mech/.

[22] R. A. Yetter, F. L. Dryer, and H. Rabitz, "A comprehensive reaction mechanism for carbon monoxide/hydrogen/oxygen kinetics," Combustion Science and Technology, vol. 79, no. 1-3, pp. 97-128, 1991.

[23] Gas turbine engine UGT 2500, http://eng.zmturbines.com/ products.html.

[24] F. Tabatabaei and M. A. Soroudi, "A kinetic study of syngas combustion characteristics for gas turbine applications," http:// www.combustion-institute.it/proceedings/MCS-7/papers/RKC/ RKC-11.pdf. 


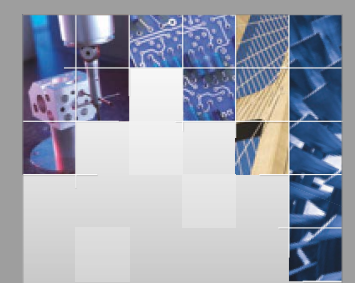

\section{Enfincering}
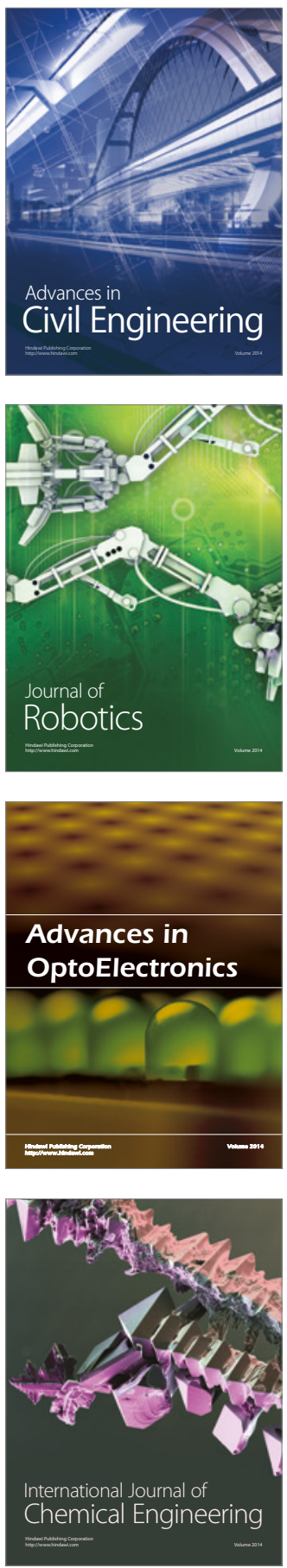

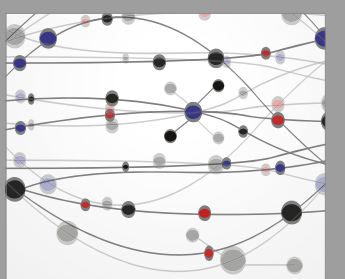

The Scientific World Journal

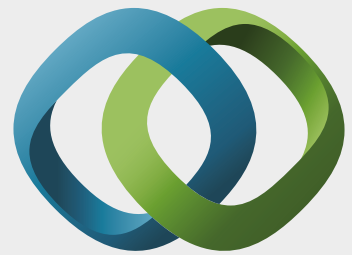

\section{Hindawi}

Submit your manuscripts at

https://www.hindawi.com
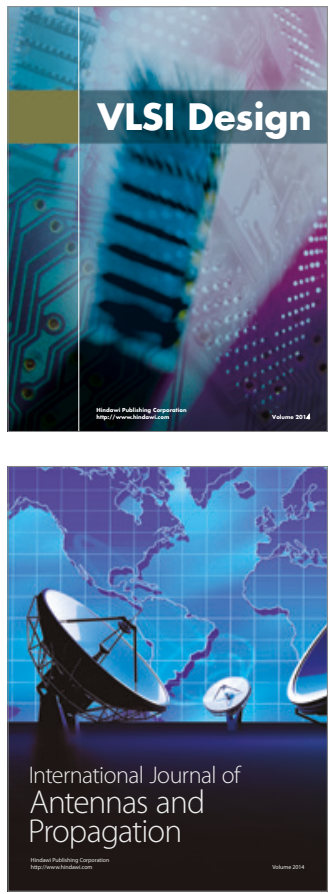

\section{Rotating}

Machinery
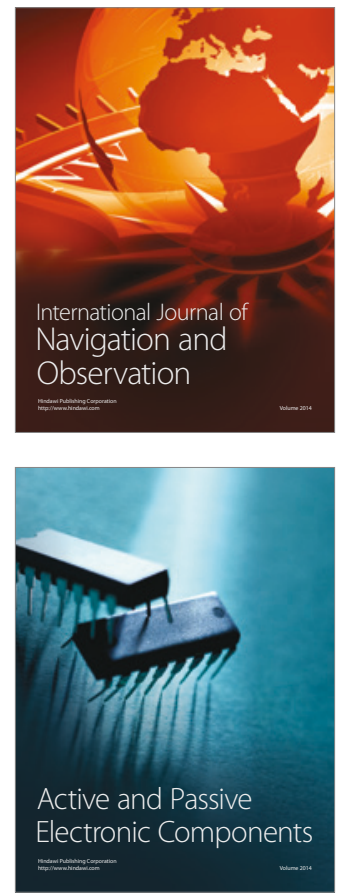
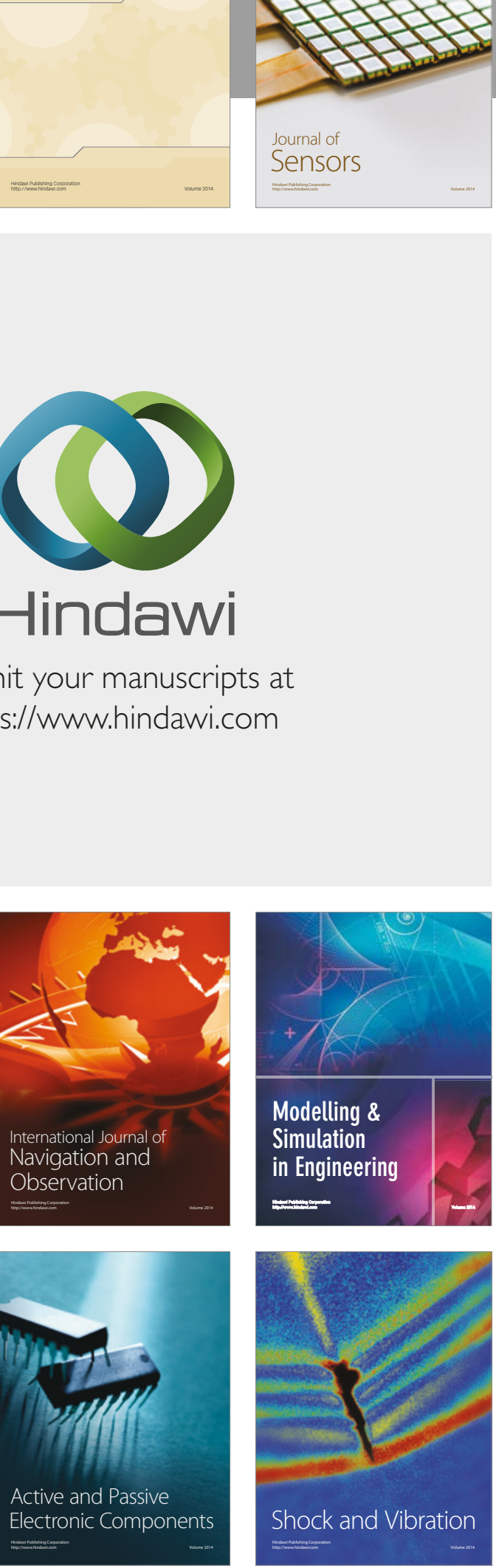
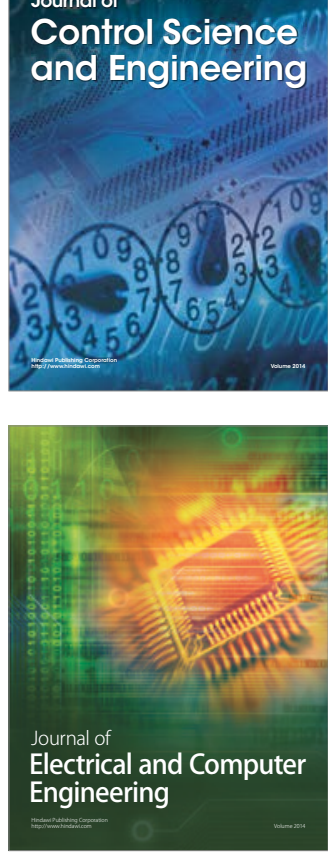

Distributed

Journal of

Control Science

and Engineering
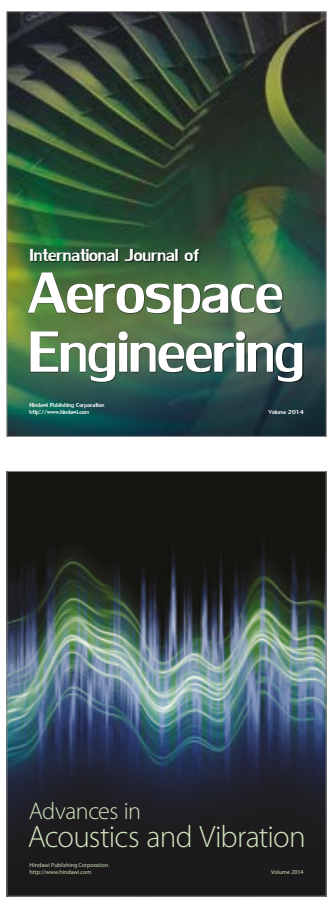

Sensor Networks 